\title{
Negotiating Egyptian Nationalism: Militant IsLamist Confrontations With the State AND THE Fragmentation of Political Authority
}

\author{
Catherine Musekamp, Simon Fraser University
}

\begin{abstract}
Since Egypt's 1952 Free Officer coup d'tat, Egypt has been governed by authoritarian regimes and nationalism has served as the central ideological basis for political authority. This paper explores the period from the mid-1970s to the mid-1990s, when militant Islamist opposition toward the Sadat and Mubarak regimes was one of the most significant threats to state security and one of the biggest challenges to the ruling regimes' hegemony over political authority. This caused the government to shift their articulations of Egyptian national identity in order to appropriate some of the religious legitimacy to which the militant Islamists were laying claim. The "Islamization" of stateendorsed Egyptian nationalism, represented primarily by the 1979/1980 amendment of the Egyptian Constitution's Article II, augmented the criteria for legitimate political participation, weakening state control over domestic political discourse. This paper argues that the negotiation of national identity was crucial to the Egyptian state's confrontation with militant Islamist groups during the late Sadat presidency and the Mubarak era to the 1990s; however, the state's endorsement of an "Islamized" Egyptian nationalism was co-opted by various state institutions and competing political groups, leading to a fragmentation of political authority.
\end{abstract}




\section{Catherine Musekamp}

$\mathrm{I}$

$\mathrm{n}$ the post-1952 Egyptian state, nationalism has been the main source of legitimacy for the state governments; ${ }^{1}$ however, the pre-eminent usage of nationalist rationale and rhetoric as a basis for political legitimacy and authority in Egypt has earlier ideological roots. Egyptians, since the nineteenth century and, particularly, in the early twentieth century during British occupation, have been engaged in discussions on national identity and affiliation. ${ }^{2}$ Moreover, in 1952, when the Free Officers successfully took control of the state in a coup détat and promoted their nationalist agenda, the authoritarian rule they consolidated marginalized competing political ideologies. In so doing, this emerging authoritarian regime was able to solidify its hold on power; however, at the same time it tied its own legitimacy inextricably to its ability to honour a recognizable nationalist agenda.

Because upholding nationalist ideology has endured as fundamental to the legitimacy of the Egyptian authoritarian regimes, ${ }^{3}$ the government's articulation of Egyptian national identity has been revised, at times, in order to accommodate new policy directions and appropriate competing sources of authority, particularly when these competing sources of authority are invoked by political actors who have opposed state policies. Indeed, this negotiation of nationalist identity has been crucial to the Egyptian state's confrontation with militant Islamist groups that pose threats to state and societal security. Addressing national identity and authoritarian rule in post-1952 Egypt is a broad topic of discussion. Even when the discussion is limited to how this relationship has become manifest in dealing specifically with violent internal conflict instigated by militant Islamist groups, the limits of this paper still prevent a full examination of the topic. Thus, the focus of this paper is restricted to addressing how Egyptian state policy has influenced, and has been influenced by, militant Islamist organizations, as well as how these state policy shifts have forced the

1 William L. Cleveland, A History of the Modern Middle East, 3rd ed. (Boulder, CO: Westview Press, 2004), 303, 308. The 1952 Free Officers' Coup, which led to the nearly two-decade long leadership of Gamal Abdel Nasser, was articulated as a movement for the nation, and the new regime actively cultivated a populist appeal; in Egypt to this day, the military coup that overthrew King Farouk is referred to as "the revolution of 1952. "

2 Ibid., 104.

3 I pluralize "regime" because it is customary to refer to the Nasser regime, the Sadat regime, and the Mubarak regime as separate, even though they have succeeded each other and are linked in political and ideological continuance. 
governing regimes to modify their articulations of the nature of Egypt's national character. While it is not possible to address every aspect or relevant instance of the relationships between militant opposition, state policy, and nationalist ideology, the earlier policies of Presidents Gamal Abdel Nasser and Anwar Sadat are addressed insofar as they provide a historical background fundamental to understanding more recent events, especially during the 1980s and 1990s when militant Islamist groups were most problematic for the Egyptian state. These decades encompass President Sadat's amendment of the Egyptian constitution asserting the pre-eminence of Islamic sources in guiding legislation, shortly followed by his assassination by militant Islamists, and the first two decades of the presidential reign of Hosni Mubarak. Before engaging in a contextual analysis, however, this paper provides a theoretical outline of the concept of nationalism, based on the works of Ernest Gellner.

"Nationalism is", according to Gellner, "the political principle which maintains that similarity of culture is the basic social bond." In the modern context, a nationalist ideology is an effective way of cultivating new authority, particularly in stages of transition; this is because developing a sense of "ethnic membership" among the populace is an effective means to "recove[r] social cohesion."5 Gellner argues that this is the case because nationalism is a rallying cry much more easily understood and felt by mass populations "than movements based on more complex considerations." ${ }^{\text {" }}$ Of course, national identity might be made up of many details, but the key notion of nationalism as being a people linked by a "shared culture"-especially when this "shared culture" is ostensibly linked to a geographical region defined by state borders-is a concept easily understood and absorbed by people regardless of education level, given the social need that humans have for community. ${ }^{7}$ Indeed, under the auspices of a "nation-state", the shared culture of a "national community" is one that is frequently searched for and cultivated in the modern period, often built upon

4 Ernest Gellner, Nationalism (London: Weidenfeld \& Nicolson, 1997), 3-4. My emphasis.

5 Ibid., 48. According to Gellner, the only context within which nationalism or any ideological unity can exist is the modern one (13).

6 Ibid.

7 Ibid., 3, states that "two general characteristics, culture and organization, are the raw material, so to speak, of all social life." 


\section{Catherine Musekamp}

ethnic ties that existed in the region prior to the emergence of the modern state. ${ }^{8}$ Through this development of nationalist ideology, state membership (citizenship) becomes intimately tied to ethnic membership.

To what degree this idea of ethnic membership and exclusivity is enforced, for Gellner, largely depends on the socio-political context at hand. Though nationalism can exist to varying degrees, Gellner states explicitly that

[i]n its extreme version, similarity of culture becomes both the necessary and the sufficient condition of legitimate membership: only members of the appropriate culture may join the unit in question, and all of them must do so. The aspirations of extreme nationalists are thwarted if their nation-state fails to assemble all the members of the nation, and if it tolerates a significant number of non-members within its borders, particularly so if they occupy places of importance. ${ }^{9}$

Moreover, in contexts where nationalism is the foundation of all political authority and legitimacy, it must embody a certain degree of the "extreme version" that Gellner discusses. Of course, depending on the characteristics of the nation, attaining membership can be a matter of acquiring and articulating certain values, or "buying in" to the legitimacy of the state to which one wishes to be bound. However, in states where political legitimacy is entirely nation-based, those who hold membership must adhere to the nationalist ideology. In such states, dissention from a nationalist regime becomes unacceptable. ${ }^{10}$

Though nationalism is often based on real shared commonalities of a people, these characteristics are selected and emphasised to the disservice of socio-cultural diversity within the same "nation" which may be as significant as the commonalities celebrated in the nationalist discourse. Furthermore, though shared commonalities may be empirically verifiable, they are often presented as being much

8 Ibid., 93-96.

9 Ibid., 4.

10 Ibid. 


\section{Negotiating Egyptian Nationalism}

more simplistic and homogenous than is actually realistic. ${ }^{11}$ For example, a nationalist advocate might identify common language as a legitimising characteristic of a nation, but fail to nuance this claim by ignoring or overlooking the existence of various dialects and forms of expression that make the "nation," in reality, quite diverse. That is not to say that nationalistic discourse is untrue, but rather, that nationalism is a perception, a lens through which one understands and articulates public discourse. On an abstract level, all forms of nationalism are of the same fabric; however, the inclusiveness and exclusiveness of nationalist ideologies exists in degrees. In all cases of nationalism, certain key criteria are inflexible for acceptance of membership. ${ }^{12}$

Nationalism is, thus, exclusive and discriminatory by nature. ${ }^{13}$ If nationalism is the dominant ideology of a state, its qualities are what render the state capable or incapable of withstanding, engaging, or incorporating competing views and ideologies. Governments inevitably govern over both supporters and dissidents; the failure of governments to engage or incorporate dissident viewpoints with those of the state can only lead to either the elimination of those who hold dissident views, or the weakening of the state by viable competing political actors. ${ }^{14}$ In the case of authoritarian states such as Egypt, the ability to incorporate competing viewpoints is more greatly hindered than in democratic states, given the exclusive dominance over political authority that the ruling regime seeks to maintain.

Egyptian nationalism as state ideology is not static and has been modified and rearticulated based on challenges the state has faced. The authoritarian regimes in Egypt since 1952 have maintained power as much through ideology as bureaucracy. ${ }^{15}$ Indeed, the shifts

11 Ibid., 7-9.

12 Ibid., 3. If "similarity of culture" is the basis of nationalist ideology, then by definition there must be an articulated cultural criterion to define a nation.

13 Ibid., 3-4.

14 Ibid., 4.

15 Cleveland, 316-22. Though the Free Officers initially "acquired legitimacy through its foreign policy ventures and Nasser's immense popularity" (316), their adoption of "Arab socialism" in 1961 led quickly into the Charter for National Action, which was "an attempt to provide ideological foundations for the regime's actions and to create mass identification with new policies" (317-18). That is not to say that the Free Officers did not have nationalist leanings early on, but rather, that they did not immediately have a cohesive ideology to guide their 


\section{Catherine Musekamp}

in the national vision of the government are usually a direct result of the state's changing policy requirements and the need to legitimise authoritarian leadership and decisions with a unifying nationalist rhetoric. Still, political challenges to the state were never fully abated, and from the mid-1970s to the end of the 1990s, militant opposition toward the authoritarian regime was a significant security threat for the Egyptian government. ${ }^{16}$

Most militant opposition against the state in Egypt charge the authoritarian regime with takfir (apostasy), given the secular nature of the state and the view that the government is attached to foreign interests and does not govern in the best interests of the Egyptian people. ${ }^{17}$ Militant Islamist groups have consistently been relegated outside the sphere of legitimate discourse by the Egyptian government, due to their violent activities and the threat they pose to the Egyptian political establishment As a result, these groups have been able to maintain their ideological cohesion and legitimacy since they articulate their own political ideologies in the vernacular of religious ethical imperatives to which the state, in their view, falls short of adhering. ${ }^{18}$ That is to say, because the views of these militant groups are consistently considered illegitimate by the state and are, thus, ignored by those holding political authority, these groups are further frustrated. From the point of view of the militant Islamists, this rejection by the political power establishment is further grounds to claim that the state regime is immoral, especially since militant Islamic groups consider their own views on state and government to be the only moral option for good governance. Shut out of legitimate dialogue, these groups view themselves as noble warriors for a just

policies: "The core group of Free Officers were pragmatic nationalists ... with no predetermined views on political organization or ideological orientation" (304).

16 James Toth, "Islamism in Southern Egypt: A Case Study of a Radical Religious Movement," International Journal of Middle East Studies 35, 4 (Nov. 2003), 54850, 567, http://www.jstor.org/stable/3879863 (accessed April 7, 2009).

17 Fawaz Gerges, The Far Enemy: Why Jihad Went Global (New York: Cambridge University Press, 2005), 46-47.

18 Saad Eddin Ibrahim, "Anatomy of Egypt's Militant Islamic Groups: Methodological Note and Preliminary Findings." International Journal of Middle East Studies 12, 4 (Dec. 1980), 429-30, http://www.jstor.org/stable/163128 (accessed October 25, 2009). 


\section{Negotiating Egyptian Nationalism}

cause. ${ }^{19}$

The phenomenon of radicalized militant Islamist ideology first emerged in Egypt in the 1970s and has proven to be of significant influence on Egyptian state security and politics despite the militants' relatively marginalized political status. ${ }^{20}$ The Egyptian government's responses to the challenge of Islamic militancy are evident in shifting policy changes which, in turn, have altered the way the state articulates Egyptian nationalism. However, the state has tried to alter the nationalist discourse only to the extent that Egyptian nationalism both retains credible unifying characteristics and reinforces the legitimacy of the ruling authority, especially in the face of significant domestic opposition from Islamist groups. For Egypt's ruling regimes, Egyptian nationalism is only as flexible as the authoritarian imperative allows; however, by the same token, the regime's domination over political authority is only as far-reaching as a plausible nationalist ideology permits it to be.

Islamism as an intellectual ideology originated in the nineteenth century. However, it first took on an organized structure with the founding of the Muslim Brotherhood in Egypt, which began as a social movement in 1928. ${ }^{21}$ Indeed, Islamism is not an inherently violent ideology or even necessarily politically oppositional to the state. $^{22}$ The unifying characteristic of Islamist organizations - social, political, militant, or otherwise - is that they all use a religious rhetoric to frame their political discourse. ${ }^{23}$ However, militant Islamist groups

19 Ibid., 430.

20 Toth, 554.

21 Richard P. Mitchell, The Society of the Muslim Brothers (London: Oxford UP, 1969), 8, 321. Mitchell notes that "[t]he Brothers saw themselves clearly in the line of the modern reform movement identified with the names of Jamal al-Din al-Afghani, Muhammad 'Abduh, and Rashid Rida” (321).

22 Ibid., 234-36. The first Islamist organization ever founded was the Muslim Brotherhood, formed under the leadership of Hassan al-Banna in 1928. Mitchell states, "The ultimate goal of the Muslim Brothers was the creation of an 'Islamic order' (al-nizam al-islami)" (234) and further that "the immediate concern of the Muslim Brothers was not the organization of a 'Muslim state' (though, as we shall see, this was considered), but rather the more profound issue of the nature and destiny of Muslim society in the twentieth century - 'the Islamic order'....' (236).

23 Dale F. Eickelman and James Piscatori, Muslim Politics, 2d ed. (Princeton: Princeton UP, 2004) 5. Eickelman and Piscatori state that "Muslim politics involves the competition and contest over both the interpretation of symbols 


\section{Catherine Musekamp}

have additional particular shared ideological characteristics. When Saad Eddin Ibrahim interviewed militant Islamists who were in prison in the late 1970s, he noted that the militants were remarkably uniform in their viewpoints, regardless of group affiliation..$^{24}$ Based on his observations, Ibrahim argued that "[m]ost crucial is the militants' belief that it is their religious duty to see to it that a truly Muslim social order comes about." 25

Militant Islamism must be understood in the Egyptian political context within which it developed. Gilles Kepel explains that militant groups are one strain of Islamism that emerged out of a period of Islamist ideological reconfiguration that occurred between the mid1950s to the mid-1960s. ${ }^{26}$ While the Muslim Brotherhood supported the 1952 coup détat, they soon found themselves in opposition to and then brutally persecuted by the Nasser regime as the new ruling government sought to consolidate power. ${ }^{27}$ Indeed, Kepel notes that in the 1960s, when the Muslim Brothers found themselves having difficulty reorienting their ideology and activities in the face of state persecution, it was Sayyid Qutb's works that "filled this ideological vacuum." ${ }^{28}$ Qutb espoused radical opposition to the state and even segments of Egyptian society and inspired many young Islamists to engage in militancy, young men who, like Qutb, knew the Nasserist state primarily through being tortured and imprisoned by agents of the

and control of the institutions, formal and informal, that produce and sustain them. The interpretation of symbols is played out against the background of an underlying framework that, while subject to contextualized nuances, is common to Muslims throughout the world."

24 Ibrahim, 427. Ibrahim explicitly locates militant Islamic groups in the realm of social movements and "define[s] 'Islamic militancy' as actual violent group behaviour committed collectively against the state or other actors in the name of Islam."

25 Ibid., 429-31. According to Ibrahim, the most striking differences between the beliefs of Egyptian militant Islamist groups is that while the vast majority of groups view the political system as un-Islamic, al-Takfir wa al-Hijra (The Repentance and the Holy Flight) make no distinction between state and society, viewing Egyptian society as essentially un-Islamic. Al-Takfir wa al-Hijra argues that state and society are "manifestations of one another." (431) Thus, it is necessary to the state in order to Egyptian society and bring back the lost moral order.

26 Gilles Kepel, Muslim Extremism in Egypt: The Prophet and Pharaoh, trans. Jon Rothschild (Berkeley, CA: University of California Press, 1985), 27, 34-35.

27 Ibid., 26-27.

28 Ibid., 37. 
government. ${ }^{29}$ Peter Mandaville concurs with Kepel's assessment and argues further that Qutb's Signposts on the Road (Ma'alim fi al-Tariq) served not just as an ideological foundation for Islamist militancy, but as a more pragmatic guide that "assumes an activist stance and then proceeds to elaborate an account of what is required of those who have already embarked 'on the path of God' ( $i$ sabil Allah)." ${ }^{30}$

Another major factor in the rise of militant Islamism was the weakening of regime legitimacy after the 1967 Arab-Israeli war, which resulted in an embarrassing military defeat for Egypt and a consequentially weakened economy. The regional-ideological supremacy of pan-Arab nationalism lost much credibility as a result of 1967, and the ideology could not hold under the failure Egypt had experienced. ${ }^{31}$ In 1970, Sadat inherited a tenuous position as the new leader of the Egyptian state, and his political decisions were constrained and guided by the need to both improve the economy and "reaffirm" Egyptian nationalism in the face of pan-Arabism's ideological downfall. Without a successful political ideological recovery, the legitimacy of Sadat's ruling authority would remain vulnerable. ${ }^{32}$ While Kepel rightly asserts that the ideological roots of militarized Islamism can be found partly in the brutality of Nasser's persecution of the Muslim Brotherhood, it was Nasser's successor, Sadat, whose policies allowed the militant movements to flourish.

The political vulnerabilities resulting from 1967 and the growing influence of leftist oppositional movements in Egypt led Sadat to release and empower the Islamists that Nasser had suppressed in the 1950s and 1960s. Sadat engaged in a limited liberalization of the

29 Ibid., 37, 63.

30 Peter Mandaville, Global Political Islam (New York: Routledge, 2007), 81. Given that Qutb's works provided the primary ideological basis for Islamist militancy, it is not surprising that Saad Eddin Ibrahim's interview research with Islamist militants in the late 1970s revealed such similar viewpoints amongst the militants, despite their various group affiliations (Ibrahim, 427).

31 Toth, 548, 555.

32 See Meir Hatina, Identity Politics in the Middle East: Liberal Thought and Islamic Challenge in Egypt (New York: Tauris Academic Studies, 2007), 29, in which he states that "[t]he decline of pan-Arabism in the wake of the defeat by Israel in 1967 resulted in a reaffirmation of Egypt's national identity, albeit with no defined ideological content." See also: Cleveland, 317. The economy was central to Nasserite ideological legitimacy. Nasser's pan-Arabism included a socialist economic platform: the state takes care of its people. 


\section{Catherine Musekamp}

public sphere, allowing strong Islamist movements to emerge on university campuses in Egypt in hopes that the increasing influence of Islamist groups would combat and stem the tide of the left-wing movements. ${ }^{33}$ However, Sadat did not apparently foresee that the rise of Islamism would take on a momentum that was beyond his ability to control. Indeed, this point is nowhere more glaring than in the irony that Sadat was eventually assassinated by a member of the Egyptian Islamic Jihad, a group that had been formed during the 1970s when Sadat was encouraging the strengthening of these Islamist groups. ${ }^{34}$

Militant Islamists argued that the only way to restore the Islamic national character of Egypt was to defeat the immoral, secular regime. ${ }^{35}$ It was this sentiment, articulated by the growing Islamist movement, that motivated Sadat's regime to explicitly alter its position on the national character of Egypt; in 1979/1980, Sadat's regime, supported by a popular referendum, amended the Egyptian constitution to make Islam the official religion of Egypt and to state that the shariah would provide the guidance for all state legislation. ${ }^{36}$ This unprecedented shift in the state's articulation of Egyptian national character was largely an attempt to undercut and appropriate some of the religious legitimacy that Islamist groups held. ${ }^{37}$

The 1970 s saw a significant increase in political power and activity from Islamist groups, both political and militant, and they proved to be much more viable and resilient than the leftist movements, which were losing relevancy in the political and economic context and seen as the ideologies of the failed era of pan-Arabism. ${ }^{38}$ These various Islamist organizations had cultivated their powerbase during Sadat's quasi-liberal period; yet while Sadat opened the public sphere for these activist groups to expand, he failed to expand the political sphere sufficiently in order to meaningfully incorporate competing views

33 Ibrahim, 426. See also Jakob Skovgaard-Peterson, Defining Islam for the Egyptian State (Leiden: Brill, 1997), 199.

34 Kepel, 191-92. Lieutenant Khalid al-Islambuli, a member of al-Jihad al-Islami, led the group that assassinated Sadat on October 6, 1981, during a military parade. Note: al-Jihad al-Islami, or Islamic Jihad, is also known as Egyptian Islamic Jihad. 35 Ibrahim, 430-31.

36 Hatina, 33. Article II of the Constitution was amended in 1979 and "ratified by a popular referendum in $1980 . "$

37 Ibid., 32-33.

38 Ibrahim, 447. 
into the discourse of government. That is to say, Sadat encouraged the Islamist presence and activities in the public sphere, thus raising their expectations for political participation; however, he failed to democratize Egypt's political system sufficiently. ${ }^{39}$ Furthermore, by making political and economic policy choices that were inflammatory - such as the influx of foreign aid to help the economy and the signing of the Camp David Accords, followed shortly by the ratification of the 1979 Egypt-Israel Peace Treaty-Sadat politically incensed these already radicalized movements at a time when his presidency was quite unpopular among the general masses. ${ }^{40}$

Though Sadat was attempting by the late 1970s to curtail the alarming expansion of radical Islamist movements through appeasement and attempting to appropriate their religious authority, his policy changes were insufficient and untimely. Sadat's assassination by Islamist militants in 1981 brought to centre stage the serious nature of this new threat to state security and the stability of the authoritarian regime. Meir Hatina makes the poignant observation that

[r]etrospectively, Sadat's assassination in 1981 exposed the paradox of the dualistic policy he adopted to curb religious radicalism: iron-fisted suppression of the militants, combined with a paternalistic approach toward Islam aimed at reinforcing the foundations of the regime. In its effort to establish Egypt as a modern national entity, the regime found itself increasingly obliged to address Islam. ${ }^{41}$

Despite the crises of the 1970s and Sadat's assassination, Sadat's successor, President Hosni Mubarak, was able to continue the political status quo and the authority of the ruling regime. Due to the Emergency Law that was implemented after Sadat's death and Mubarak's certain degree of military legitimacy, Mubarak was able to maintain authoritarian rule; however, Mubarak's credibility as a leader was not comparable to the credibility that Nasser or Sadat had

39 Hatina, 31-32, further observes that "[t]he relatively liberal period [of Sadat's presidency] also fostered the convergence of a parliamentary opposition ... [which] ... added a pluralistic element to the political scene but remained noninfluential, overshadowed by the powerful institution of the presidency."

40 Ibrahim, 426-27. See also Toth, 549, 558.

41 Hatina, 32-33. 


\section{Catherine Musekamp}

possessed. ${ }^{42}$ When Mubarak took power, he embarked on a series of political and legal reforms in order to consolidate and secure his powerbase. ${ }^{43}$ In line with Sadat's constitutional amendment, Mubarak continued the paradoxical trend of "Islamizing" Egyptian identity, while at the same time trying to maintain the secular quality of Egyptian state operations. ${ }^{44}$ Though the state's official title is the Arab Republic of Egypt, Sadat's amendment made the second article of Egypt's constitution to state not only that Islam is Egypt's official religion, but that shari'a is "the principle source of legislation." ${ }^{45}$ While Sadat may have been the one to amend the Constitution, Mubarak found it politically prudent to uphold and emphasize this shift "by increasing the exposure of religious themes in the media, censoring books and plays offensive to Islam or Islamic morality, and instituting prayer services in government offices," as well as opening up a somewhat controlled "public dialogue" with the regime's religious opposition. ${ }^{46}$

In the 1980s and 1990s, Egypt's most pressing domestic crisis was the growing strength of militant Islamist groups within its borders. ${ }^{47}$

42 Hesham al-Awadi, In Pursuit of Legitimacy: The Muslim Brothers and Mubarak, 1982-2000 (New York: Tauris Academic Studies, 2004), 44-45, 49, 54. Amr Hamzawy, "Amending Democracy Out of Egypt's Constitution," The Washington Post, April 2, 2007, Monday; http://www.washingtonpost.com/wp-dyn/content/ article/2007/04/01/AR2007040100595.html (accessed November 30, 2009). The Emergency Law policies remained enacted until 2007, at which point they were simply ratified into regular state law in a constitutional amendment (rigged) vote. According to Amr Hamzawy, this was an attempt by "the regime [to] create a new set of tools to control the electoral process and ensure its continued hegemony over Egypt's politics."

43 Al-Awadi, 49.

44 Hatina, 36.

45 The Arab Republic of Egypt Constitution, Pt. 1, Art. 2. (available at http:// www.egypt.gov.eg/english/laws/Constitution/chp_one/part_one.aspx) states that "Islam is the religion of the state and Arabic its official language. Principles of Islamic law (sharia) are the principal source of legislation" (my emphasis). Egypt's state nationalism is "secular" in the sense that it purports to encompass all Egyptians regardless of religious affiliation; however, since taking power, the Mubarak regime has consistently sought to articulate and support an Islamic quality of Egyptian nationalism in the face of continuing Islamist challenged to his regime's ruling authority.

46 Hatina, 35.

47 Al-Awadi, 117, 153. 
These militant groups initially gained momentum when the state and its nationalist ideology were relatively weak. Ibrahim argues of the 1970s emergence of militant Islamist groups that

[i]n the absence of a credible, secular national vision and lacking effective means to repel external encroachment, to enhance the present and future socioeconomic prospects of the middle and lower classes, and to galvanize the imagination of the educated youth and give them a sense of being essential parts of a grand design, Islamic militancy becomes the alternative. ${ }^{48}$

James Toth's analysis of the further increase of militant Islamist membership and activity in the 1980s and 1990s supports Ibrahim's argument. Toth notes that many who joined militant groups in the mid-1980s were of Upper Egyptian origin. Many southern Egyptians had pursued education in Cairo under Nasser's state-sponsored education policies of the 1960s, only to find themselves socially and economically marginalized because they were "bereft of the family connections and the parlour mannerisms" required to enter into the opportunity of "Cairene elite society." 49 The promises of Arab unity and equal opportunity proved worthless for rural Egyptians seeking upward socioeconomic mobility. Though in the 1970s and 1980s many of the newly educated young men travelled abroad to other Arab states for work, "beginning in 1985, when regional oil revenues began to decline, these professionals returned home to the Said to stay." ${ }^{\prime 50}$ Excluded from the opportunities that better-connected Egyptians had in their own country, some of these unemployed professionals-many of whom were involved in university campus Islamist movements in the 1970s-found a channel for their "moral outrage" in militant Islamist ideology. ${ }^{51}$

Given their rural connections, these middle-class ideologues were able to cultivate a following among the "disgruntled members of the

48 Ibrahim, 448.

49 Toth, 554.

50 Ibid., 554-55. Note: Sa id is another name for southern Egypt. The region is also referred to as "Upper Egypt" in relation to its location upstream on the Nile River.

51 Ibid., 555. 


\section{Catherine Musekamp}

working class" who also had experience with rural-urban migration and found, instead of the fulfillment of the promise of Cairo's urban opportunity, economic disappointment and cultural discrimination. ${ }^{52}$ The Islamist loyalties cultivated in the southern villages "were readily transferred" to Cairo-based Islamist groups "[w]hen employment later shifted to the city" and these loyalties provided social support and valuable socioeconomic connections. ${ }^{53}$ Though not all rural Islamists joined the urban-based militant movements, those who did, often did so in response to the state's seeming abandonment of the rural south in terms of social support and infrastructure, ${ }^{54}$ as well as the state's persecution of Islamist groups and failure to provide adequate social and economic opportunity. ${ }^{55}$ A common sentiment among Sa'idis was that "as long as the government denied [Islamist movements] a legitimate channel for influencing state policy ... the more its collective alienation would turn to unlawful acts of violence."56

During the height of Egypt's Islamist militancy, the main sources of tension between the militants and the state lay with domestic political issues and discontent with the authoritarian regime responsible for their continuance. ${ }^{57}$ Increasing economic class divides agitated a longstanding feeling of disenfranchisement by poor and middle-class Egyptians. Members of Egypt's lower and middle classes, seeing their hardships in the face of the privileged lifestyle of the elite, provided a large pool of potential recruits for militant Islamist ideologues. ${ }^{58}$ Furthermore, the political exclusion and repression of Islamist opposition by the ruling regime only reinforced this sense of injustice once marginalized individuals were recruited to a militant group. ${ }^{59}$ Being denied dignity, opportunity, and a political voice was a plight known to many Egyptians; for some, militant opposition was the answer to a regime built on these hardships. ${ }^{60}$

52 Ibid.

53 Ibid., 555-59.

54 Ibid., 554.

55 Ibid., 560-61.

56 Ibid., 560.

57 Gerges, The Far Enemy, 43-45.

58 Toth, 554.

59 Ibid., 560.

60 Ibid., 556-67. 
While it may be debatable whether or not the various political grievances at hand necessitated the destruction of Egypt's entire political system, these militant groups often claimed this was the only solution to Egypt's ills. ${ }^{61}$ As Toth's account suggests, the violent tactics of some Islamist groups toward the Egyptian government was not so much a result of unchangeable and irreconcilable ideological views, but rather a manifestation of frustration toward the authoritarianguided nationalist ideology and the Egyptian regime's reluctance to accept and engage competing political actors. Instead, the Mubarak regime, like its predecessor, attempted to appropriate religious sources of legitimization and into its own nationalistic vision.

Unlike the leftist movements of the Nasser and Sadat periods and the liberal democratic movements of the Mubarak era, Islamist movements cannot be dismissed as products of foreign influence threatening to compromise Egypt's national character. ${ }^{62}$ Islam has long been a significant characteristic of Egyptian society. ${ }^{63}$ Because of the religious, indigenous quality of Islamist movements, the Egyptian ruling powers have had to tread carefully when attempting to contain them, lest their actions appear to be anti-Islamic. The difficulty of this balancing act was apparent during the 1990s; when the heightened levels of Islamist violence meant the urgent need for the state to suppress the Islamist militias, the Mubarak regime found itself subject to, and forced to accept, criticism from religious authorities at al-

61 Gerges, The Far Enemy, 44.

62 Ibrahim, 447. Ibrahim comments on the political tactic that the ruling regime often used of exploiting postcolonial anxieties about foreign influence, noting that "the ruling elite [are able to] to dismiss leftist and Marxist opponents as atheists or agents of a foreign power (usually the Soviet Union) who are bent on destroying Islamic and authentic national heritage...It is much harder to use the same propaganda weapon, however, against groups proclaiming Islam as their ideology, especially when those groups are avowedly opposed to foreign influence-Soviet, Western, and Zionist." Accusing government opponents of being under foreign influence was a tactic used by the Egyptian government up until the downfall of Mubarak in February 2011, although the impact of such accusations have become less significant as years of Egyptian independence distance the current socio-political climate from the British occupation of Egypt in the first half of the twentieth century. See Abu Atris, "Mubarak's Failed Last Stand," Al Jazeera English (February 11, 2011), http://english.aljazeera.net/ indepth/opinion/2011/02/2011211143148924996.html (accessed February 11, 2011).

63 Ibrahim, 425. 


\section{Catherine Musekamp}

Azhar University. ${ }^{64}$

Though al-Azhar was nationalized by Nasser in 1954 and has long been financially under state control, ${ }^{65}$ the Mubarak regime did not possess the political capital to both aggressively go after the Islamic militant groups and ignore the criticism and demands of the religious authorities at al-Azhar. Doing so would make the regime appear as if it were attacking Islam on all fronts. ${ }^{66}$ Instead, Mubarak was forced to concede and-to appear to be upholding the "[p]rinciples of Islamic law (sharía) [as] the principal source of legislation" ${ }^{\prime \prime}$ —adopt certain policy changes in line with the views coming from al-Azhar. ${ }^{68}$

Tamir Moustafa argues that, while al-Azhar condemned militant Islamists for their ideology and actions, the preeminent religious institution also used the crisis these groups presented to the state to forward its own interests. ${ }^{69} \mathrm{Al}$-Azhar provided support by lending its religious credibility to the Mubarak regime, but it also took advantage of the political situation at hand. While the Egyptian government was focused on quashing the Islamist militant security threat that was destabilizing the country, al-Azhar used "its new-found space and leverage to pursue broader interests that extended far beyond the role that the government prescribed." ${ }^{\prime 0}$ In the mid-1990s, al-Azhar

64 Tamir Moustafa, "Conflict and Cooperation between the State and Religious Institutions in Contemporary Egypt," International Journal of Middle East Studies 321 (Feb. 2000), 3, http://www.jstor.org/stable/259533 (accessed October 16, 2009). Moustafa states that "Al-Azhar [is] traditionally Egypt's most respected and influential center for Islamic study."

65 Cleveland, 321.

66 Moustafa, 15, argues that "[t]he government's reluctance ... to punish alAzhar for its increasingly vocal opposition to a wide variety of state policies was due to the uncomfortable position that the government faced. Although the state had proved its capacity to manipulate al-Azhar in the past, it became increasingly dependent on al-Azhar to discredit radical Islamists on theological grounds. Further, the tight government control of al-Azhar lends support to the extremists' contention that the secular state is corrupting and manipulating Islam for its own gain."

67 The Arab Republic of Egypt Constitution, Pt. 1, Art. 2.

68 Moustafa, 3, 15.

69 Moustafa, 12, states that al-Azhar has "three central interests: 1. to maintain its institutional autonomy; 2. to preserve its respected status in Egyptian society by maintaining its informal role as the pre-eminent interpreter of Islamic texts and traditions; and 3. to safeguard and encourage the propagation of Islam."

70 Moustafa, 13. 


\section{Negotiating Egyptian Nationalism}

became a vocal opponent of many government policies, including the government illegalization of female genital mutilation (FGM) and Egypt's hosting of the United Nations International Conference on Population and Development (ICPD) in 1994, mainly due to "the conference's platform regarding sexual relationship and abortion rights." ${ }^{\prime 1}$ Moustafa concedes that, while this may have resulted in bad press for the Mubarak regime, these criticisms did not actually result in government policy changes toward either FGM or the ICPD. However, al-Azhar's increasing influence did seem to manifest explicitly in a 1994 ruling by the Egyptian State Council on censorship that upgraded al-Azhar's position from an advisory relationship with the Ministry of Culture to being "the final arbiter in the assessment of the Islamic factor, whose opinion is binding for the Ministry of Culture concerning the granting or refusing of a license for audio and audiovisual productions." 72 The vocal criticisms of the government by al-Azhar and the religious institutions increasing influence led some observers to question who was managing whom in the relationship between the Egyptian government and its ostensible branch, alAzhar. $^{73}$

The Mubarak regime was also forced to give an unprecedentedly uncensored voice to moderate Islamist groups. While both the Muslim Brotherhood and a younger group of moderate political Islamists, whom Raymond Baker calls "the New Islamists"-represented politically by al-Wasat Party-released statements in the late 1980s condemning extremist militant Islamist groups that waged violence in Egypt, these oft politically marginalized groups also placed calls for "moderate reform" in order to address "the shortcomings of corruption, repression, and unmet mass needs in existing structures

\section{Ibid.}

72 Ibid., 14, quoting the Egyptian Organization for Human Rights (EOHR), Freedom of Opinion and Belief: Restrictions and Dilemmas: Proceedings of the Workshop on the Azhar's Censorship of Audio and Audiovisual Productions (Cairo: EOHR, 1994), 30.

73 Ibid., 15, quotes Egyptian university lecturer 'Asim al-Disuqi, who "expressed the dismay of many intellectuals and secular government officials, saying: 'This fatwa marks a new phase in the relationship between al-Azhar and the state. The state has been using al-Azhar since $1895 \ldots .$. The fatwa, however, changes the course of this relationship; it is al-Azhar that is now using the state through its own State Council." 


\section{Catherine Musekamp}

and policies." 74 The Muslim Brotherhood went even further, calling for more immediate changes. Baker describes the criticisms levelled in the Muslim Brotherhood statement:

[The Muslim Brotherhood] argues that the outbreaks of violence result from the continued enforcement of the stateof-emergency laws. Moreover, they seize on this moment to argue that the mass discontents rocking the country have their origin in the serious economic failures of the regime. They charge that the state-controlled media are fostering a climate of decadence and authoritarianism, while blocking Islamist channels for reform. They argue that an oppressive law governing the formation of parties prevents the Muslim Brothers from operating legally as a political party - a party that could answer the urgent "popular demand" of the Egyptian people for an Islamic political orientation that would address these pressing national failures. ${ }^{75}$

Thus, moderate Islamist groups were able to press for a dialogue, one tied to their unequivocal condemnation of militant Islamist violence. The New Islamists and the Muslim Brotherhood both vouched for the "Islamic" nature of the regime in order to combat the militant charge that the regime was un-Islamic, but they also called for reform for the well-being of Egypt. It is indeed notable that these calls for change were made in the name of the nation, not of religion. ${ }^{76}$

As distasteful and condemnable as political violence is generally regarded to be, the consequences of the conflict instigated by these militant Islamist groups have been farther reaching than the obvious influence militant threats have had on the Islamization of Egyptian law and politics. This incorporation of Islam as an explicit and central component of Egypt's national character resulted in varying degrees of fragmentation in Egyptian nationalist discourse and political authority. In order to effectively combat the imminent threat of Islamist militancy without losing too much moral credibility, it was politically necessary for Mubarak to recognise other sources

74 Raymond Baker, Islam Without Fear: Egypt and the New Islamists (Cambridge, MA: Harvard University Press, 2003), 87.

75 Ibid., 88-89.

76 Ibid., $87-89$. 
of Islamic authority, conceding social and political legitimacy to figures outside of his ruling political circle. ${ }^{77}$ The regime had to allow previously controlled or excluded voices into the nationalist political discourse. The various concessions that the Mubarak regime had to make, in particular toward al-Azhar and moderate flanks of the Muslim Brotherhood in the 1990s, demonstrated an increasing fragmentation of authority in the Egyptian political sphere. Without engaging with competing religious actors like al-Azhar and moderate Islamist groups, it is doubtful the Mubarak regime would have been able to maintain its religious credibility.

A case in point is the infamous 1997 "Satanists" incident. The Mubarak regime, in an attempt to both enhance its own religious image and distract the increasingly concerned Egyptian public from the Islamic militancy issue in the country, arrested scores of heavy metal "fans and musicians [who] were arrested and charged with, among other things, being Satanists and killing cats in Satanic rituals." 78 According to Benjamin Harbert, at least seventy-eight students were sent to prison. Herbert argues that "the government's brutal crackdown, informed by their high-stakes wrangling with radical Islamic groups, was a calculated strategy that held up this group of 'practicing Satanists' as a straw man against which to redefine its defense of Islam." ${ }^{\prime 9}$ However, this attempt by the regime to appear as a staunch defender of Islam backfired quickly. According to Mark LeVine,

[t]he Egyptian media, unable to criticize the government for its policies, picked up on the affair as an excuse to rebuke the President for not protecting Islam against foreign threats, just at the moment when radical Islamist terrorism was becoming

77 Moustafa, 13-18. The two major groups who benefited from Mubarak's political concessions were the religious authorities at al-Azhar and the moderated Muslim Brotherhood.

78 Mark LeVine, "Doing the Devil's Work: Heavy Metal and the Threat to Public Order in the Muslim World," Social Compass 56, 4 (2009), 571, http://scp.sagepub. com/content/56/4/564.refs.html (accessed February 25, 2011).

79 Benjamin J. Harbert (forthcoming), "Noise and Its Formless Shadows: Egypt's Extreme Metal as Avant-Garde Nafas Dowsha," in The Arab Avant Garde: Musical Innovation in the Middle East, ed. Thomas Burkhalter, Kay Dickinson and Benjamin J. Harbert (Middletown, CT: Wesleyan University Press), [np]. 


\section{Catherine Musekamp}

a serious threat to the government. ${ }^{80}$

While the incident and the regime's sensationalist propaganda may have succeeded in making the Egyptian public "wary of metal" and dividing Egyptian society in this way, ${ }^{81}$ it did little to improve the regime's Islamic credentials and perhaps even damaged them.

In understanding and interpreting politicized Islamic rhetoric, it is important to acknowledge the absence of a central authority figure or homogeneous body of jurisprudence in Sunni Islam. ${ }^{82}$ In addition, recent centuries of colonialism and modern state-building led to power shifts and an erosion of the authority traditionally held by religious jurists and institutions, which resulted in a "crisis of [religious] authority." 83 Thus, in Egypt, where Islam is the shared faith of the majority population and is recognised by all political players as a key component of the national character, ${ }^{84}$ the legitimacy that religious invocation can confer onto political actors is not absolute and can be continuously contested by those who seek an avenue to

\section{LeVine, 571-72.}

81 Harbert notes that Egyptian metal fans were harshly marginalized and that "[a]fter the arrests, most metalheads either left Egypt or cut their hair to disappear into more conventional Egyptian lives. Those who did not live in fear of misinformed vigilante justice, not uncommon in Egypt." [np].

82 Khaled Abou el Fadl, Speaking in God's Name: Islamic Law, Authority and Women (Oxford: Oneworld, 2001), 30-40.

83 Khaled Abou El Fadl, “The Roots of the Problem," in The Great Theft: Wrestling Islam from the Extremists (New York: Harper Collins, 2007), 26-27. This is especially true in the modern state period, where there has been an erosion of religious institutions and jurisprudential tradition resulting in what Khaled Abou el Fadl has termed a religious "crisis of authority."

84 Abu 'Ila Madi, Rafiq Habib and Karim al-Gawhary, "We are a Civil Party with an Islamic Identity': An Interview with Abu 'Ila Madi Abu 'Ila and Rafiq Habib," Middle East Report 199 (Apr.-Jun. 1996), 30-32, http://www.jstor.org/ stable/3012891 (accessed February 24, 2011). Even many Coptic Christian political actors recognize this aspect of Egypt's national character. Well-known Coptic intellectual and co-founder of al-Wasat party, Rafiq Habib, addressed this aspect of Egyptian identity in a 1996 interview, stating "Our [al-Wasat's] Islamic identity is both religious and cultural. When we speak about al-Wasat, we refer to a cultural identity which all people, whether in Egypt or any other Arab country, have in common, be they Christians or Muslims .... As an Arab Christian, I identify with the value system of the Arab and Islamic civilization which expresses my feelings and preferences" (30). 
attain power through moral legitimacy. ${ }^{85}$

Unlike more moderate Islamist movements in Egypt, Islamist militant groups never had widespread support. Indeed, Fawaz Gerges states that it was largely the widespread public condemnation that ultimately led to the marginalization and near extinguishment of these militant groups from the Egyptian socio-political scene. Their violent activities alienated the Egyptian public, who responded by denying these groups any support or shelter from the Egyptian government. Eventually, "strategic blunders" resulted in their being driven almost entirely underground and many groups, for all intents and purposes, disbanded ${ }^{86}$ However, while these groups did not participate in legitimate political discourse or cultivate any significant popular following, this paper has endeavoured to show the indirect effect militant Islamist groups had on the expansion of political discourse and authority in Egypt. Before the threat of these groups faded, the Mubarak regime had to take steps to control and eliminate them and this led to a pragmatic political step of giving space for other prominent religious voices of authority. While Mubarak saw this inclusion as a way of counteracting the militant claims of religious legitimacy, the result was the bolstering of moderate religious voices whose views Mubarak could not manipulate.

Islamist opposition movements-militant and nonviolent-have proven their longevity in the Egyptian socio-political scene. Ibrahim argued in his 1980 article that Islamist movements are able to root themselves more deeply in Egyptian socio-political thought than other ideologies because the religious discourse they employ is familiar to the majority of Egyptians, regardless of education level or social class. ${ }^{87}$ Indeed, it appears that Islamist groups, particularly militant ones, have been highly effective at contesting Egyptian national identity and fragmenting political authority. By contesting aspects of

85 Abou El Fadl, “The Roots of the Problem," 38-39. “The vacuum in authority meant not so much that no one could authoritatively speak for Islam, but that virtually every Muslim with a modest knowledge of the Qur'an and the traditions of the Prophet was suddenly considered qualified to speak for the Islamic tradition and sharía law...."

86 Fawaz Gerges, "The End of the Islamist Insurgency in Egypt?: Costs and Prospects," Middle East Journal 54, 4 (Autumn 2000), 593-94, http://www.jstor. org/stable/4329545 (accessed 8 February 2011). Gerges also notes that these groups had internal fractures that weakened them considerably.

87 Ibrahim, 448. 


\section{Catherine Musekamp}

Egypt's "shared culture" and shifting the emphasis regarding which qualities are important to the nature of Egyptian nationalism, these groups challenged the core of the legitimacy of Egypt's authoritarian governments. Until the early 2000s, Islamist groups arguably posed the biggest threat to the ruling regime and the most impactful force of political fragmentation and, thus, democratization in the Arab Republic of Egypt.

This paper's focus was on the effects of militant Islamism on nationalist discourse in an era of Egyptian politics that came to a close in the late 1990s; however, I feel it would be negligent to not acknowledge the remarkable events that have taken place in recent weeks. The uprising that began on January 25, 2011, galvanized by a youth-led resistance movement that has been building itself since the early 2000s, is not only a political revolution, but a social one as well. These events are changing the way Egyptians understand themselves vis-à-vis the power of the state. The ousting of former president Hosni Mubarak on February 11, 2011 has ushered in a new era of Egyptian politics and nationalist discourse. The non-ideological revolution that is unfolding brings the potential for an entirely new way of shaping Egyptian nationalism and politics.

The undefined qualityofthis revolution means that the longstanding outcome of this event remains to be seen. However, it is worthy of note that this is the first time Egypt has seen a strong non-Islamist political movement pose a serious challenge to the authoritarian regime, and this movement has already been successful in toppling Mubarak and irreversibly changing Egypt's political landscape. Clearly, this youthled movement has had a greater impact on Egypt's post-1952 political society than any other opposition movement thus far. For the first time, we are seeing a viable and vibrant alternative to an explicitly "Islamicized" Egyptian nationalism. It is uncertain whether or not Article II will remain in its current form and survive the evolution of Egypt's Constitution, or if Egyptian nationalism and state politics will be taken in an entirely new direction. It is certain, however, that if this revolution succeeds in producing a new democratic Egypt, Islamist groups such as the Muslim Brotherhood will once again be forced to grapple with a reconfiguration of their ideologies, and their ways of maintaining their relevancy and forwarding their goals. 


\section{Bibliography}

Abou El Fadl, Khaled. Speaking in God's Name: Islamic Law, Authority and Women. Oxford: Oneworld, 2001.

_ "The Roots of the Problem." In The Great Theft: Wrestling Islam from the Extremists, 26-44. New York: Harper Collins, 2007.

Al-Awadi, Hesham. In Pursuit of Legitimacy: The Muslim Brothers and Mubarak, 1982-2000. New York: Tauris Academic Studies, 2004.

The Arab Republic of Egypt Constitution, Part 1, Article 2, English translation: http://www.egypt.gov.eg/english/laws/Constitution/ chp_one/part_one.aspx.

Baker, Raymond. Islam Without Fear: Egypt and the New Islamists. Cambridge, MA: Harvard University Press, 2003.

Cleveland, William L. A History of the Modern Middle East, 3rd ed. Boulder, CO: Westview Press, 2004.

Eickelman, Dale F., and James Piscatori. Muslim Politics, 2d ed. Princeton: Princeton University Press, 2004.

Harbert, Benjamin J. (forthcoming). "Noise and Its Formless Shadows: Egypt's Extreme Metal as Avant-Garde Nafas Dowsha." In The Arab Avant Garde: Musical Innovation in the Middle East, ed. Thomas Burkhalter, Kay Dickinson and Benjamin J. Harbert. Middletown, CT: Wesleyan University Press.

LeVine, Mark. "Doing the Devil's Work: Heavy Metal and the Threat to Public Order in the Muslim World," Social Compass 56, 4 (2009): 564-76. http://scp.sagepub.com/content/56/4/564.refs. html (accessed February 25, 2011).

Madi, Abu 'Ila, Rafiq Habib, and Karim al-Gawhary, "We are a Civil Party with an Islamic Identity': An Interview with Abu 'Ila Madi Abu 'Ila and Rafiq Habib" Middle East Report 199 (Apr-Jun 1996): 30-32. http://www.jstor.org/stable/3012891 (accessed February 24, 2011). 


\section{Catherine Musekamp}

Gellner, Ernest. Nationalism. London: Butler \& Tanner Ltd., 1997.

Gerges, Fawaz. "The End of the Islamist Insurgency in Egypt?:

Costs and Prospects." Middle East Journal 54, 4 (Autumn 2000): 592-12, http://www.jstor.org/stable/4329545 (accessed February $8,2011)$.

Gerges, Fawaz. The Far Enemy: Why Jihad Went Global. New York: Cambridge University Press, 2005.

Hatina, Meir. Identity Politics in the Middle East: Liberal Thought and Islamic Challenge in Egypt. New York: Tauris Academic Studies, 2007.

Ibrahim, Saad Eddin. "Anatomy of Egypt's Militant Islamic Groups: Methodological Note and Preliminary Findings." International Journal of Middle East Studies 12, 4 (Dec 1980): 423-53, http:// www.jstor.org/stable/163128 (accessed October 25, 2009).

Kepel, Gilles. Muslim Extremism in Egypt: The Prophet and Pharaoh, trans. Jon Rothschild. Berkeley, CA: University of California Press, 1985.

Mitchell, Richard P. The Society of the Muslim Brothers. London: Oxford University Press, 1969.

Moustafa, Tamir. "Conflict and Cooperation between the State and Religious Institutions in Contemporary Egypt." International Journal of Middle East Studies 32, 1 (Feb 2000): 3-22, http:// www.jstor.org/stable/259533.

Skovgaard-Peterson, Jakob. Defining Islam for the Egyptian State: Muftis and Fatwas of the Dar al-Ifta. Leiden: Brill, 1997.

Toth, James. "Islamism in Southern Egypt: A Case Study of a Radical Religious Movement." International Journal of Middle East Studies 35, 4 (Nov 2003): 547-72, http://www.jstor.org/ stable/3879863. 